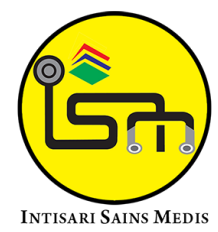

Published by Intisari Sains Medis

\title{
Efektifitas dan keamanan dari terapi kombinasi methotrexate dan secukinumab pada Psoriasis vulgaris berat: tinjauan sistematis
}

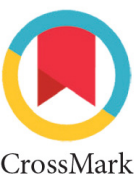

\author{
Ovienanda Kristi Purbasari ${ }^{1}$,Ni Putu Wina Widyastuti2 ${ }^{2 *}$, Carolina Senak ${ }^{3}$
}

'Raya Kuta Clinic, Badung, Bali, Indonesia 2Puskesmas Mengwi II, Badung, Bali, Indonesia ${ }^{3}$ Rumah Sakit Royal Progress Sunter, Jakarta, Indonesia
*Korespondensi:

Ni Putu Wina Widyastuti; Raya Kuta Clinic, Badung, Bali, Indonesia;

widyastutiwina@gmail.com
Diterima: 27-07-2021

Disetujui: 30-11-2021

Diterbitkan: 28-12-2021

\section{ABSTRACT}

Introduction: Psoriasis is a chronic inflammatory disease of the skin that requires comprehensive treatment. Combination therapy can be a good option in optimizing psoriasis treatment outcomes. However, the effectiveness and safety of combination therapy are still not fully understood. This study reviewed the literature examining the effectiveness and safety of the combination treatment of secukinumab and methotrexate in patients with severe Psoriasis vulgaris. Methods: A literature search was performed on PubMed and Google Scholar databases, with several inclusion criteria. The research method used is a case report and controlled trial, with the critical appraisal method using the JBI Critical Appraisal.

Result: There were 6 pieces of literature that met the inclusion criteria. All literature describes in detail the clinical condition, course of the disease, management and side effects of treatment, but supporting examinations are not specifically described. In general, all literature shows a clinical improvement in severe

Keywords: Methotrexate, secukinumab, severe psoriasis vulgaris

Cite This Article: Purbasari, O.K., Widyastuti, N.P.W., Senak, C. 2021. Efektifitas dan keamanan dari terapi kombinasi methotrexate dan secukinumab pada Psoriasis vulgaris berat: tinjauan sistematis. Intisari Sains Medis 12(3): 921-926. D0l: 10.15562/ism.v12i3.1097

\section{ABSTRAK}

Pendahuluan: Psoriasis merupakan penyakit inflamasi kronik pada kulit yang membutuhkan penanganan yang baik. Terapi kombinasi dapat menjadi pilihan yang baik dalam mengoptimalkan luaran pengobatan psoriasis. Namun, efektifitas dan keamanan terapi kombinasi masih belum dipahami sepenuhnya dan masih harus di pertimbangkan. Studi ini menilai beberapa literatur yang menguji efektifitas dan keamanan dari pengobatan kombinasi secukinumab dan methotrexate pada pasien dengan Psoriasis vulgaris berat.

Metode: Pencarian literatur dilakukan pada database psoriasis patients who are given combination treatment, and some literature also explains systemic side effects and residual plaque. The combination of biological agents with conventional systemic treatment has been proposed to optimize the results of psoriasis treatment. One study reported lightweight gastrointestinal disorders related to the use of a combination of secukinumab and methotrexate administration along with biological agents that could prevent or reduce the development of anti-drug antibodies and increase response levels to treatment. Advanced research is still needed in assessing this specific mechanism for this combination therapy

Conclusion: Combination therapy of secukinumab and methotrexate is effective in treating psoriasis skin manifestations without significant side effects. This drug combination is useful in overcoming the limitations of monotherapy drugs, such as decreasing effectiveness due to prolonged use.
PubMed dan Google Scholar, dengan beberapa kriteria inklusi. Metode penelitian yang digunakan adalah case report dan controlled trial, dengan metode critical appraisal menggunakan JBI Critical Appraisal.

Hasil: Didapatkan sebanyak 6 literatur yang memenuhi kriteria inklusi. Semua literatur menjelaskan secara detail terkait kondisi klinis, perjalanan penyakit, tatalaksana dan efek samping pengobatan, namun pemeriksaaan penunjang tidak dijelaskan secara spesifik. Secara umum, semua literatur menunjukan adanya perbaikan klinis pada pasien psoriasis berat yang diberikan pengobatan kombinasi, beberapa 
literatur juga menjelaskan efek samping sistemik dan plak residu. Terapi kombinasi agen biologis dengan pengobatan sistemik konvensional telah diusulkan untuk mengoptimalkan hasil pengobatan psoriasis. Satu studi melaporkan adanya gangguan gastrointestinal ringan terkait penggunaan kombinasi secukinumab dan methotrexate. Pemberian methotrexate bersamaan dengan agen biologis dapat mencegah atau mengurangi pengembangan antibodi anti-drug dan meningkatkan tingkat respon terhadap pengobatan. Penelitian lanjutan tetap diperlukan dalam menilai mekanisme spesifik terapi kombinasi ini. Kesimpulan: Terapi kombinasi secukinumab dan methotrexate efektif dalam mengobati manifestasi kulit psoriasis tanpa adanya efek samping bermakna. Kombinasi obat ini berguna dalam mengatasi keterbatasan obat monoterapi, seperti efektifitas yang menurun akibat penggunaan yang berkepanjangan.

Kata Kunci: Methotrexate dan secukinumab, psoriasis vulgaris berat.

Sitasi Artikel ini: Purbasari, 0.K., Widyastuti, N.P.W., Senak, C. 2021. Efektifitas dan keamanan dari terapi kombinasi methotrexate dan secukinumab pada Psoriasis vulgaris berat: tinjauan sistematis. Intisari Sains Medis 12(3): 921-926. D0l: 10.15562/ism.v12i3.1097

\section{PENDAHULUAN}

Psoriasis adalah kondisi proliferatif dan inflamasi kronis pada kulit. Hal ini ditandai dengan plak eritematosa bersisik terutama pada permukaan ekstensor, kulit kepala, dan daerah lumbosakral. Psoriasis tidak dapat disembuhkan dan sering kali bertambah berat seiring waktu. Banyak pasien psoriasis mengalami depresi karena kualitas hidup yang buruk. Terdapat beberapa subtipe psoriasis tetapi manifestasi berupa plak adalah yang paling umum terjadi dan biasa muncul di ekstremitas dan kulit kepala. ${ }^{1}$ Bentuk klinis psoriasis yang paling sering terlihat, Psoriasis vulgaris, mencakup hampir $90 \%$ kasus. Lesi menunjukkan distribusi simetris, dan paling sering terlokalisasi pada lutut, siku, kulit kepala, dan daerah sakral. Lesi ini biasa muncul setelah kejadian traumatis pada lokasi yang bersangkutan. ${ }^{2}$ Baik dalam praktik klinis dan uji klinis, tingkat keparahan psoriasis sering dikategorikan sebagai ringan, sedang, dan berat, yang dipandu oleh pengukuran seperti luas permukaan tubuh (body surface area; BSA), Physician's Global Assessment (PGA), dan The Psoriasis Area And Severity Index (PASI). ${ }^{3}$ Atas dasar ini, tingkat keparahan psoriasis ditentukan menggunakan kriteria berikut, diantaranya ringan (PASI $<7$ dan DLQI $<$ 7); sedang (PASI $=7-15$ dan DLQI $=5-15$ (diklasifikasikan sebagai parah bila lokasi yang sulit diobati terpengaruh atau bila ada dampak psikososial yang signifikan)); dan berat (PASI> 15, terlepas dari skor
DLQI). ${ }^{4}$

Meskipun tidak ada pengobatan definitif untuk psoriasis, terdapat beberapa pilihan pengobatan yang efektif. Terapi topikal adalah standar perawatan untuk pengobatan penyakit ringan sampai sedang. Sebagian besar pasien akan mendapat manfaat dari terapi topikal, yang dapat diberikan pada fasilitas kesehatan primer. Jika agen topikal tidak memberikan respon yang memadai pasien dapat diberikan terapi sistemik dengan tambahan topikal..$^{5}$ Secukinumab, antibodi monoklonal IgG1, secara selektif mengikat IL-17A dan disetujui oleh FDA Amerika Serikat dan badan obat Eropa untuk Psoriasis vulgaris sedang hingga berat dan Psoriasis arthritis. ${ }^{6}$ Terapi kombinasi agen biologis dengan obat sistemik konvensional dapat berguna untuk mengoptimalkan hasil pengobatan psoriasis. Terapi kombinasi memiliki kemampuan untuk mengatasi keterbatasan obat individu, termasuk kurangnya efektifitas karena penggunaan yang berkepanjangan dan efek samping terkait. Selain itu, obat dengan mekanisme kerja yang berbeda memberikan efek sinergis, mengurangi dosis yang diperlukan dari masingmasing agen tunggal, sehingga membatasi efek samping. Pemberian methotrexate secara bersamaan dapat meningkatkan tingkat respon pengobatan psoriasis berat menurut beberapa studi penelitian. ${ }^{7,8} \mathrm{Pada}$ studi ini bertujuan untuk mengetahui efektifitas dan keamanan dari terapi kombinasi methotrexate dan secukinumab pada Psoriasis vulgaris berat.

\section{METODE}

\section{Strategi pencarian literatur}

Pencarian literatur dilakukan pada database PubMed dan Google Scholar pada tanggal 10 April, 2021. Pencarian literatur menggunakan kata kunci "Psoriasis vulgaris", "Secukinumab", "Methotrexate", dan kata kunci terkait lainnya (Tabel 1). Hasil pencarian literatur dan kriteria inklusi serta eksklusi dapat dilihat pada Gambar 1.

\section{Kriteria literatur}

Tinjauan kepustakaan ini dilakukan dengan membatasi jurnal bahasa Inggris maupun Indonesia, dipublikasikan dalam 10 tahun terakhir, dan tidak memungut biaya. Pencarian awal menemukan sebanyak 414 literatur. Setelah menerapkan kriteria inklusi dan eksklusi serta membaca literatur secara lengkap, didapatkan sebanyak 6 literatur.

Artikel ini mencakup penelitian yang dilakukan oleh Tiberio et al., Jensen Yeung et al., Phung et al., Kostaki et al., Thibodeaux et al., dan Gisondi P et al..$^{9-14}$ Metode penelitian yang digunakan pada peneliti tersebut adalah case report dan controlled trial. Metode critical appraisal yang digunakan untuk case report dalam penelitian ini adalah JBI Critical Appraisal.

\section{HASIL}

Relevansi dari ke-6 penelitian ini dinilai berdasarkan karakteristik demografi, kelengkapan anamnesis dan pemeriksaan fisik, kondisi klinis awal pasien, 
pemeriksaan penunjang, tatalaksana, efek samping, dan aplikasinya ke praktik klinis (Tabel 2).

Penelitian yang dilakukan oleh Kotsaki et al. melaporkan kasus seorang wanita 70 tahun dengan psoriasis plak sedangberat disertai Psoriasis arthritis. ${ }^{12}$ Pasien mengalami gejala psoriasis plak pada saat usia 50 tahun dengan keluhan awal berupa poliartritis perifer simetris. Pasien sudah diberikan terapi topikal namun tidak ada respon. Sebelum diberi pengobatan, plak pada tubuh mencakup 45\% BSA dan skor PASI 26. Pasien awalnya diberikan methotrexate oral $15 \mathrm{mg}$ dan menunjukkan perbaikan klinis namun fungsi hepar menurun secara signifikan sehingga pengobatan dihentikan. Pasien selanjutnya diberikan pengobatan injeksi subkutan secukinumab $300 \mathrm{mg}$ tiap minggu disertai pemberian methotrexate injeksi 10 mg. Setelah 24 minggu pengobatan, lesi di tubuh hanya berupa eritema ringan mencakup 1\% dari BSA dan skor PASI 1,2. Pada studi tersebut pasien tidak mengeluhkan adanya efek samping.

Penelitian lainnya yang dilakukan oleh Phung et al. menjelaskan 2 kasus psoriasis berat yang diberikan kombinasi pengobatan secukinumab dengan methotrexate. ${ }^{11}$ Pasien pertama yaitu wanita 52 tahun dengan psoriasis di kaki dan siku. Pasien awalnya mengonsumsi 15 mg methotrexate, namun infeksi bakteri kulit muncul. Pasien mengalami remisi pada 12 minggu pengobatan. Saat pasien usia 65 tahun, keluhan muncul kembali dan diberikan secukinumab $300 \mathrm{mg}$ tiap 2 minggu disertai methotrexate. Setelah 12 minggu pengobatan, lesi sekarang hanya berupa plak kecil di siku. Tidak ada efek samping yang dilaporkan selama pengobatan. Kasus kedua adalah seorang wanita 38 tahun dengan lesi plak tebal di kulit kepala, siku, dan lutut. Selain itu terdapat beberapa lesi plak tipis di beberapa bagian tubuh. Pasien diberikan injeksi secukinumab $300 \mathrm{mg}$ tiap 2 minggu disertai methotrexate. Setelah 22 minggu pengobatan, lesi plak tebal menghilang dan hanya terdapat beberapa plak residu di siku dan lutut. Tidak ada efek samping yang dilaporkan.

Penelitian yang dilakukan oleh Jensen Yeung et al. mencakup pasien 50 tahun dengan riwayat 14 tahun psoriasis plak

Tabel 1. Strategi pencarian di PubMed dan Google Scholar yang dilakukan di tanggal 10 April 2021.

\begin{tabular}{llc}
\hline \multicolumn{1}{c}{ Sumber } & \multicolumn{1}{c}{ Kata kunci } & Artikel yang ditemukan \\
\hline PubMed & $\begin{array}{l}\text { "Psoriasis" and ("methotrexate" OR "MTX") } \\
\text { and "secukinumab" }\end{array}$ & 85 \\
Google Scholar & $\begin{array}{l}\text { "Psoriasis" and ("methotrexate" OR "MTX") } \\
\text { and "secukinumab" and "combination } \\
\text { therapy." }\end{array}$ & 329 \\
\hline
\end{tabular}
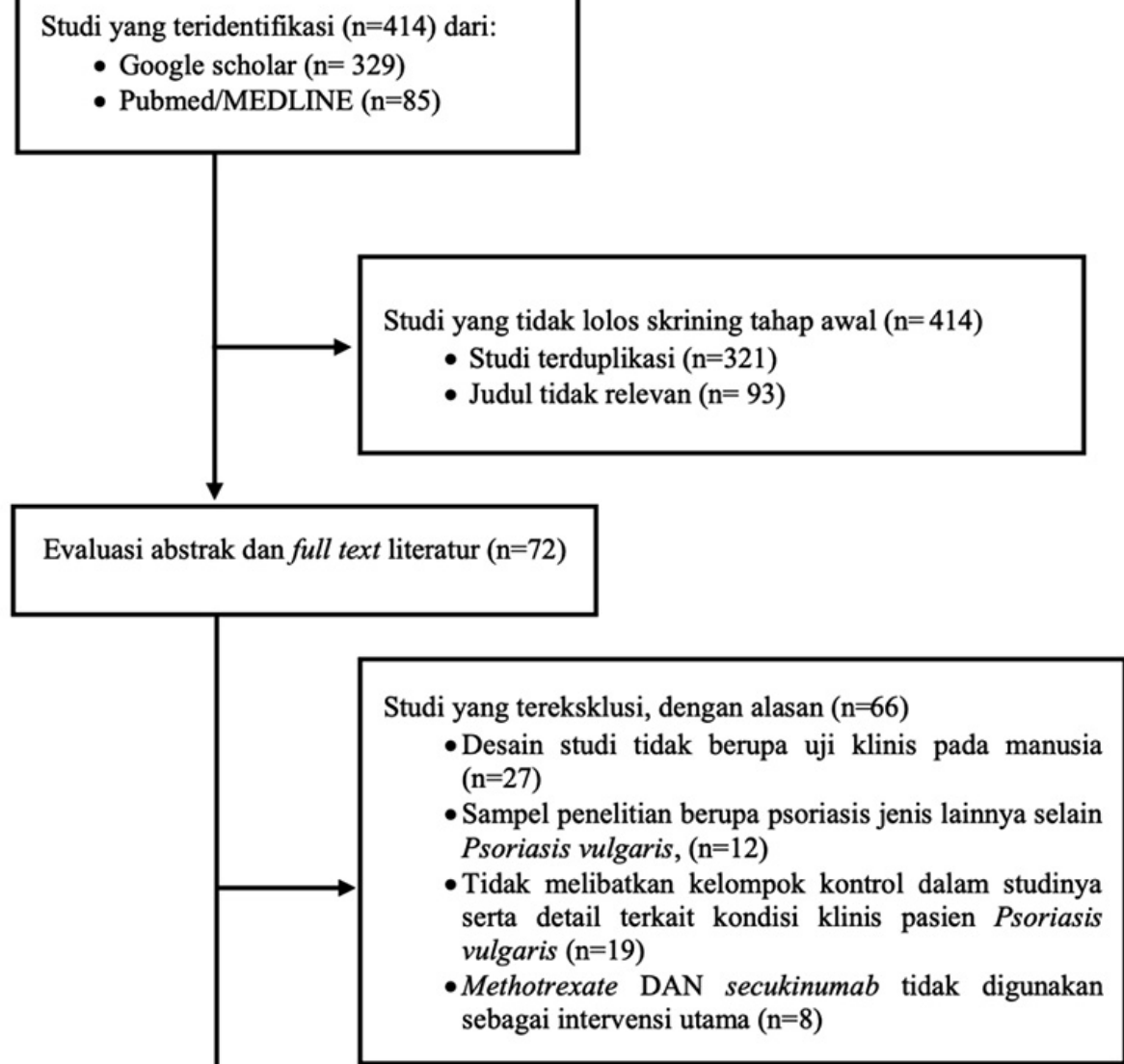

Studi yang memenuhi kriteria eligibilitas dan diikutsertakan dalam analisis $(\mathrm{n}=6)$

Gambar 1. Diagram PRISMA studi.

berat. ${ }^{10}$ Pasien sudah mencoba beberapa pengobatan topikal dan terapi ultraviolet namun tidak ada respon. Lesi plak psoriasis mencakup 50\% BSA dengan skor PASI 29,3 . Pasien diberikan pengobatan injeksi secukinumab $300 \mathrm{mg}$ pada minggu 0,1 , 2, 3, 4, dan selanjutnya 4 minggu sekali. Pasien diberikan tambahan injeksi SC methotrexate 15 minggu pada saat minggu ke 3 pengobatan secukinumab. Setelah 3 bulan pengobatan, skor BSA pasien yaitu $8 \%$, dengan skor PASI 4,6. Setelah 6 bulan pengobatan, pasien kembali ke klinik dan mengeluhkan terdapat manifestasi gastrointestinal sehingga pasien menghentikan pengobatan methotrexate. Pada pemeriksaan dapat dijumpai terdapat lesi plak residu yang mencakup skor BSA $2 \%$ dan skor PASI 3,0 .

Penelitian lainnya dilakukan oleh 
Tabel 2. Critical Appraisal

\begin{tabular}{|c|c|c|c|c|c|c|c|c|}
\hline Pengarang & & & & Critical App & al Checklist & & & \\
\hline & $\begin{array}{l}\text { Apakah } \\
\text { karakteristik } \\
\text { demografis } \\
\text { pasien } \\
\text { dijelaskan? }\end{array}$ & $\begin{array}{l}\text { Apakah } \\
\text { perjalanan } \\
\text { penyakit } \\
\text { dijelaskan } \\
\text { secara } \\
\text { terperinci? }\end{array}$ & $\begin{array}{l}\text { Apakah } \\
\text { kondisi klinis } \\
\text { pasien saat } \\
\text { presentasi } \\
\text { awal } \\
\text { dijelaskan? }\end{array}$ & $\begin{array}{l}\text { Apakah } \\
\text { pemeriksaan } \\
\text { penunjang } \\
\text { atau metode } \\
\text { diagnosis } \\
\text { dijelaskan? }\end{array}$ & $\begin{array}{l}\text { Apakah } \\
\text { tatalaksana } \\
\text { yang } \\
\text { diberikan } \\
\text { dijelaskan } \\
\text { secara } \\
\text { terperinci? }\end{array}$ & $\begin{array}{l}\text { Apakah } \\
\text { kondisi } \\
\text { paska- } \\
\text { pengobatan } \\
\text { dijelaskan? }\end{array}$ & $\begin{array}{l}\text { Apakah } \\
\text { efek } \\
\text { samping } \\
\text { dijelaskan? }\end{array}$ & $\begin{array}{l}\text { Apa laporan } \\
\text { kasus ini dapat } \\
\text { dijadikan } \\
\text { pembelajaran? }\end{array}$ \\
\hline Kotsaki et al. & $\checkmark$ & $\checkmark$ & $\checkmark$ & - & $\checkmark$ & $\checkmark$ & $\checkmark$ & $\checkmark$ \\
\hline Phung et al. & - & $\checkmark$ & $\checkmark$ & - & $\checkmark$ & $\checkmark$ & $\checkmark$ & $\checkmark$ \\
\hline Jensen et al. & $\boldsymbol{J}$ & $\boldsymbol{J}$ & $\boldsymbol{\Omega}$ & - & $\checkmark$ & $\checkmark$ & $\boldsymbol{\Omega}$ & $\checkmark$ \\
\hline Tiberio et al. & $\checkmark$ & $\checkmark$ & $\checkmark$ & - & $\checkmark$ & $\checkmark$ & $\checkmark$ & $\checkmark$ \\
\hline $\begin{array}{l}\text { Thibodeaux } \\
\text { et al. }\end{array}$ & $\checkmark$ & $\sqrt{ }$ & $\sqrt{ }$ & - & $\boldsymbol{J}$ & $\checkmark$ & $\boldsymbol{J}$ & $\checkmark$ \\
\hline $\begin{array}{l}\text { Gisondi P } \\
\text { et al. }\end{array}$ & $\checkmark$ & $\checkmark$ & $\checkmark$ & $\checkmark$ & $\checkmark$ & $\checkmark$ & $\checkmark$ & $\checkmark$ \\
\hline
\end{tabular}

Tiberio et al. mencakup pasien wanita usia 58 tahun dengan psoriasis berat yang memiliki skor PASI 24. ${ }^{9}$ Pasien juga obesitas dengan skor BMI 49,59. Pasien diberikan terapi methotrexate 15 minggu per minggu dan secukinumab $300 \mathrm{mg}$ pada minggu $0,1,2,3$, dan 4 yang kemudian dilanjutkan tiap 4 minggu sekali. Lesi kulit membaik saat 3 bulan kemudian dengan skor PASI 6. Namun setelah 6 bulan pengobatan, didapatkan skor PASI 0. Pasien tidak melaporkan adanya efek samping selama pengobatan.

Penelitian yang dilakukan oleh Thibodeaux et al. mencakup wanita 38 tahun dengan riwayat psoriasis generalisata berat sejak usia 12 tahun. ${ }^{13}$ Sejak usia 19 tahun pasien didiagnosis Psoriasis arthritis. Pasien diberikan terapi secukinumab $300 \mathrm{mg}$ selama 2 minggu disertai pemberian methotrexate. Namun tidak terdapat perbaikan secara klinis. Pengobatan pasien ditambah dengan etanercept 50 minggu tiap minggu dimana baru terdapat perbaikan pada Psoriasis arthritis namun perburukan pada manifestasi kulit selama 6 bulan. Selanjutnya pengobatan pasien diganti menjadi guselkumab monoterapi dengan dosis bervariasi dari $100 \mathrm{mg}$ tiap 8 minggu sampai $100 \mathrm{mg}$ tiap 4 minggu. Manifestasi kulit pada pasien membaik secara signifikan. Pasien tidak melaporkan adanya efek samping selama pengobatan.
Penelitian yang dilakukan oleh Gisondi $\mathrm{P}$ et al. mencakup 130 pasien dengan riwayat psoriasis dengan disertai penyakit sindrom metabolik. ${ }^{14}$ Pasien yang terlibat dalam studi meliputi laki-laki dan wanita yang berusia $>18$ tahun yang terjangkit psoriasis sedang hingga berat yang disertai dengan riwayat penyakit sindrom metabolik. Pada studinya, pasien yang memenuhi syarat secara berurutan diberi rasio 1:1 untuksecukinumab (dosis standar) atau methotrexate $15 \mathrm{mg} / \mathrm{minggu}$ dengan pemberian subkutan dan suplementasi asam folat $5 \mathrm{mg}$ diberikan 24 jam setelah methotrexate. Parameter penilaian yang dilakukan yakni melakukan penilaian skor PASI 75 dan 90 pada pasien setelah 6 bulan dan 12 pengobatan, disamping parameter lainnya yang ditinjau terkait dengan efek samping yang ditimbulkan pada hasil pemeriksaan darah. Efikasi pengobatan methotrexate secara signifikan lebih rendah dibandingkan dengan secukinumab baik pada bulan ke 6 atau 12. Secara khusus, PASI 75 dan PASI 90 dicapai oleh $82 \%$ dan $71 \%$ pasien yang diobati dengan secukinumab dibandingkan dengan $55 \%$ dan $31 \%$ pasien yang diobati dengan methotrexate $(\mathrm{P}<0,001)$ pada bulan 6. PASI 75 dan PASI 90 dicapai oleh $76 \%$ dan $61 \%$ pasien yang diobati dengan secukinumab dibandingkan dengan 52\% dan $28 \%$ pasien yang diobati dengan methotrexate $(\mathrm{P}<0,001)$ pada bulan $12 .^{14}$

\section{DISKUSI}

Penggunaan obat-obatan biologis untuk pengobatan psoriasis sedang hingga berat menghasilkan peningkatan yang signifikan pada kesehatan pasien. Berkat peningkatan pemahaman mengenai regimen pengobatan untuk pasien psoriasis maka pengobatan harus disesuaikan untuk memenuhi kebutuhan spesifik berdasarkan tingkat keparahan penyakit, dampak pada kualitas hidup, respons terhadap terapi sebelumnya, dan adanya penyakit penyerta. Beberapa strategi digunakan untuk menangani pasien yang tidak responsif terhadap terapi konvensional. Terapi kombinasi agen biologis dengan pengobatan sistemik konvensional telah diusulkan untuk mengoptimalkan hasil pengobatan psoriasis. $^{7,14}$ Manfaat terapi kombinasi adalah kemampuan untuk mengatasi keterbatasan obat individu, seperti efektifitas yang menurun akibat penggunaan yang berkepanjangan. Selain itu, obat dengan mekanisme kerja yang berbeda memberikan efek aditif atau sinergis, mengurangi dosis yang diperlukan dari masingmasing agen tunggal, yang berdampak pada penurunan risiko efek samping. Pemberian methotrexate bersamaan dengan agen biologis dapat mencegah atau mengurangi pengembangan antibodi anti-drug, dan meningkatkan tingkat 
respons terhadap pengobatan. ${ }^{8}$ Selain itu, dosis methotrexate dapat dikurangi bila obat biologis ditambahkan, dengan penurunan risiko toksisitas organ akhir pada pasien kardiomiopati atau risiko perlemakan hati dan fibrosis hepar pada pasien obesitas, dimana keduanya terkait dengan penggunaan obat-obatan jangka panjang. ${ }^{15,16}$

Secukinumab adalah inhibitor interleukin-17A yang telah menunjukkan efektifitas yang tinggi dalam pengobatan psoriasis berat dan artritis psoriasis (PsA). Pengobatan ini menunjukkan onset kerja yang cepat, respon berkelanjutan, profil keamanan yang menguntungkan, dan peningkatan kualitas hidup pasien. ${ }^{17}$ Sedangkan, methotrexate dapat mengontrol penyakit dengan baik dan dapat meningkatkan kualitas hidup pasien psoriasis. Efek optimal dari methotrexate umumnya terjadi dalam 5 sampai 6 bulan terapi. Sekitar $50-70 \%$ pasien merasakan hasil yang baik dari terapi methotrexate, yang memberikan penurunan $75 \%$ pada skor PASI. ${ }^{18,19}$

Kombinasi terapi secukinumab dan methotrexate dilaporkan pada enam penelitian yang dibahas sebelumnya. Dari ke-6 penelitian, hanya penelitian yang dilakukan oleh Thibodeaux et al. yang menunjukkan kegagalan dalam terapi kombinasi secukinumab dan methotrexate pada Psoriasis vulgaris berat. ${ }^{13}$ Penelitian yang dilakukan oleh Tiberio et al. bahkan melaporkan remisi lengkap dimana didapatkan skor PASI 0 setelah 6 bulan pengobatan. ${ }^{9}$ Penelitian lainnya melaporkan terdapat residu plak meskipun hanya sedikit. Rata rata waktu yang dibutuhkan untuk mencapai remisi yaitu 6 bulan pengobatan. ${ }^{10-12}$

Mekanisme yang mendasari efek kombinasi secukinumab atau methotrexate belum diketahui. Secara khusus, peran methotrexate dalam penghambatan imunogenisitas tampaknya tidak relevan dalam kasus ini, karena secukinumab terbukti memiliki potensi yang sangat rendah dalam menginduksi antibodi anti-drug, jika dibandingkan dengan agen biologis lain yang saat ini digunakan dalam pengobatan psoriasis. ${ }^{20,21}$ Namun, terdapat penelitian yang dilakukan oleh Choquette et al. yang menjelaskan bahwa kombinasi secukinumab dengan methotrexate pada pasien psoriasis tidak meningkatkan efektifitas pengobatan. ${ }^{22}$

Dosis secukinumab yang direkomendasikan untuk pasien Psoriasis vulgaris berat adalah $300 \mathrm{mg}$ yang diberikan secara subkutan pada minggu ke $0,1,2,3$, dan 4 (dosis awal), dan setiap 4 minggu setelahnya (dosis maintenance). Sedangkan dosis awal methotrexate dalam uji coba terkontrol secara acak bervariasi dari 5 sampai $25 \mathrm{mg} /$ minggu dimana paling sering dengan dosis $7,5 \mathrm{mg}$ atau 15 mg. Pedoman yang merekomendasikan bervariasi dari 5 hingga $15 \mathrm{mg} /$ minggu. $^{23,24}$ Pada lima penelitian dalam studi yang dibahas sebelumnya telah menunjukkan bahwa sudah sesuai dengan pedoman.

Sampai saat ini, laporan penelitian yang menganalisis kombinasi secukinumab dengan methotrexate sangat terbatas sehingga efektifitas dan efek samping masih belum dipahami seutuhnya. Dari ke-6 penelitian tersebut, hanya penelitian yang dilakukan oleh Jensen Yeung et al. yang melaporkan terdapat gangguan gastrointestinal terkait penggunaan kombinasi secukinumab dan methotrexate. ${ }^{10}$ Namun menurut teori, pemberian methotrexate dapat mempengaruhi seluruh tubuh sehingga efek yang tidak diharapkan dapat terjadi. Efek tak terduga dari obat ini adalah anemia, leukopenia, mual, ulserasi oral, pneumonitis, supresi hematopoietik, gangguan hepar, dan ginjal. ${ }^{24}$ Sedangkan efek samping yang umum dari pengobatan secukinumab termasuk sakit kepala dan nasofaringitis. Pasien yang diobati dengan secukinumab telah terbukti, dalam uji coba tahap II dan III, memiliki peningkatan risiko kandidiasis mukokutan, yang dapat berhasil diobati dengan terapi oral atau topikal dan biasanya tidak memerlukan penghentian terapi secukinumab. ${ }^{23}$

Berkaitan dengan beberapa studi yang telah dijelaskan sebelumnya, penelitian ini terdapat beberapa keterbatasan. Pertama, penelitian ini hanya menggunakan artikel bahasa Inggris atau Indonesia, sehingga penelitian yang menggunakan bahasa lain tidak dapat dilakukan analisis lebih mendalam. Selain itu, penelitian ini hanya mencakup penelitian dengan metode case report dikarenakan keterbatasan literatur dengan topik terkait sehingga hasil penelitiannya kurang kuat.

\section{SIMPULAN}

Tinjauan kepustakaan ini menggunakan 6 penelitian berbeda dan menyimpulkan bahwa terapi kombinasi secukinumab dan methotrexate efektif dalam mengobati manifestasi kulit psoriasis tanpa adanya efek samping bermakna. Kombinasi obat ini berguna dalam mengatasi keterbatasan obat monoterapi, seperti efektifitas yang menurun akibat penggunaan yang berkepanjangan. Selain itu, obat dengan mekanisme kerja yang berbeda memberikan efek sinergis, mengurangi dosis yang diperlukan dari masing-masing agen tunggal, yang berdampak pada penurunan risiko efek samping. Namun dikarenakan penelitian yang membahas pengobatan kombinasi ini masih sangat terbatas sehingga diperlukan penelitian lebih lanjut.

\section{KONFLIK KEPENTINGAN}

Penulis menyatakan tidak terdapat konflik kepentingan terkait publikasi dari artikel ini.

\section{PENDANAAN}

Penelitian ini tidak mendapat dana hibah dari pemerintah maupun lembaga swasta lainnya.

\section{KONTRIBUSI PENULIS}

Penulis berkontribusi terhadap penelitian ini baik dari perencanaan hingga interpretasi dan penyusunan naskah publikasi.

\section{DAFTAR PUSTAKA}

1. Nair PA, Badri T. Psoriasis. In: StatPearls. Treasure Island (FL): StatPearls Publishing; August 11, 2021.

2. Sarac G, Koca TT, Baglan T. A brief summary of clinical types of psoriasis. North Clin Istanb. 2016;3(1):79-82. Published 2016 Jun 14. doi:10.14744/nci.2016.16023.

3. Strober B, Ryan C, Van De Kerkhof P, et al. Recategorization of psoriasis severity: Delphi consensus from the International Psoriasis Council. J Am Acad Dermatol. 2019;82(1). p117-122. doi:10.1016/j.jaad.2019.08.026.

4. Llamas-Velasco M, de la Cueva P, Notario J, Martínez-Pilar L, Martorell A, MorenoRamírez D. Moderate Psoriasis: A Proposed Definition. Psoriasis moderada. Propuesta de definición. Actas Dermosifiliogr. 2017. 108(10). p911-917. doi:10.1016/j.ad.2017.07.002. 
5. Kim WB, Jerome D, Yeung J. Diagnosis and management of psoriasis. Can Fam Physician. 2017;63(4):278-285.

6. Berg SH, Balogh EA, Ghamrawi RI, Feldman SR. A review of secukinumab in psoriasis treatment. Immunotherapy. 2021;13(3):201216. doi:10.2217/imt-2020-0195.

7. Jensen P, Skov L, Zachariae C. Systemic combination treatment for psoriasis: A review. Acta Derm Venereol. 2010;90(4):341-349. doi:10.2340/00015555-0905.

8. Farhangian ME, Feldman SR. Immunogenicity of biologic treatments for psoriasis: therapeutic consequences and the potential value of concomitant methotrexate. Am J Clin Dermatol. 2015;16(4):285-294. doi:10.1007/ s40257-015-0131-y.

9. Tiberio R, Graziola F, Miglino B, Veronese F, Annali G, Savoia P: Secukinumab for Psoriasis in Obese Patients: Minireview and Clinical Experience. Case Rep Dermatol 2019;11(suppl 1):29-37. doi: 10.1159/000501990.

10. Yeung J, Valbuena V. Successful use of secukinumab in pustular psoriasis. JAAD Case Reports. 2016;2(6):470-472. doi:10.1016/j. jdcr.2016.05.006.

11. Phung M, Georgakopoulos JR, Ighani A, Giroux L, Yeung J. Secukinumab dose optimization in adult psoriasis patients: A retrospective, multicenter case series. JAAD Case Rep. 2018;4(4):310-313. Published 2018 Mar 31. doi:10.1016/j.jdcr.2017.11.006.

12. Kostaki D, Aquila E, Macaluso L, Mattozzi C, Richetta AG. Optimizing Secukinumab Treatment in Psoriasis with Concomitant Methotrexate Administration: Minireview and A Case Report. Case Rep Dermatol. 2019;11(Suppl 1):17-22. Published 2019 Sep 23. doi:10.1159/000501994.
13. Thibodeaux Q, Ly K, Reddy V, Smith MP, Liao W. Dual biologic therapy for recalcitrant psoriasis and psoriatic arthritis. JAAD Case Rep. 2019;5(10):928-930. Published 2019 Oct 10. doi:10.1016/j.jdcr.2019.08.015.

14. Gisondi P, Bellinato F, Bruni M, De Angelis G, Girolomoni G. Methotrexate vs secukinumab safety in psoriasis patients with metabolic syndrome. Dermatol Ther. 2020;33(6):e14281. doi:10.1111/dth.14281.

15. Rønholt K, Iversen L. Old and New Biological Therapies for Psoriasis. Int $\mathrm{J}$ Mol Sci. 2017;18(11):2297. Published 2017 Nov 1. doi:10.3390/ijms18112297.

16. Prodanovich S, Ma F, Taylor JR, Pezon C, Fasihi T, Kirsner RS. Methotrexate reduces incidence of vascular diseases in veterans with psoriasis or rheumatoid arthritis [published correction appears in J Am Acad Dermatol. 2005 Apr;52(4):670. Prodanowich, Srdjan [corrected to Prodanovich, Srdjan]]. J Am Acad Dermatol. 2005;52(2):262-267. doi:10.1016/j. jaad.2004.06.017.

17. Kaushik SB, Lebwohl MG. Psoriasis: Which therapy for which patient: Psoriasis comorbidities and preferred systemic agents. J Am Acad Dermatol. 2019;80(1):27-40. doi:10.1016/j.jaad.2018.06.057.

18. Bissonnette $\mathrm{R}$, Luger $\mathrm{T}$, Thaçi $\mathrm{D}$, et al. Secukinumab demonstrates high sustained efficacy and a favourable safety profile in patients with moderate-to-severe psoriasis through 5 years of treatment (SCULPTURE Extension Study). J Eur Acad Dermatol Venereol. 2018;32(9):1507-1514. doi:10.1111/ jdv.14878.

19. Haider S, Wahid Z, Najam-Us-Saher, Riaz F. Efficacy of Methotrexate in patients with plaque type psoriasis. Pak J Med Sci. 2014;30(5):10501053. doi:10.12669/pjms.305.4451.

20. Warren RB, Mrowietz U, von Kiedrowski $\mathrm{R}$, et al. An intensified dosing schedule of subcutaneous methotrexate in patients with moderate to severe plaque-type psoriasis (METOP): a 52 week, multicentre, randomised, double-blind, placebo-controlled, phase 3 trial. Lancet. 2017;389(10068):528-537. doi:10.1016/ S0140-6736(16)32127-4.

21. Spindeldreher S, Maillère B, Correia E, et al. Secukinumab Demonstrates Significantly Lower Immunogenicity Potential Compared to Ixekizumab [published correction appears in Dermatol Ther (Heidelb). 2018 Mar 17;:]. Dermatol Ther (Heidelb). 2018;8(1):57-68. doi:10.1007/s13555-018-0220-y.

22. Choquette D, Bessette L, Sauvageau LC, et al. AB0740 Use of secukinumab in patients with psoriatic arthritis. Impacts of combination with methotrexate. In: Abstracts Accepted for Publication. BMJ; 2019:1835.1-1835. doi:10.1136/annrheumdis-2019-eular.3132

23. Yang EJ, Beck KM, Liao W. Secukinumab in the treatment of psoriasis: patient selection and perspectives. Psoriasis (Auckl). 2018;8:7582. Published 2018 Oct 17. doi:10.2147/PTT. S146004.

24. Agustina M, Hidayati AN, Hasanatuludhhiyah N. Side Effects of Methotrexate for Psoriasis Therapy. Berk Ilmu Kesehat Kulit dan Kelamin. 2020;32(2):98. doi:10.20473/bikk. v32.2.2020.98-102.

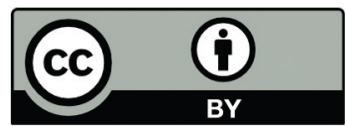

This work is licensed under a Creative Commons Attribution 